\title{
Sarin poisoning of a rescue team in the Matsumoto sarin incident in Japan
}

Department of Hygiene, Shinshu University School of Medicine, Matsumoto, 390, Japan

T Nakajima

\section{Department of}

Internal Medicine, Marunouchi Hospital, Matsumoto, 390, Japan S Sato

\section{Department of} Medicine (Neurology), Shinshu University School of Medicine, Matsumoto, 390 Japan H Morita

$\mathrm{N}$ Yanagisawa

Correspondence to: Dr Tamie Nakajima, Department of Hygiene, Shinshu University School of Medicine, Asahi 3-1-1 Matsumoto 390, Japan.

\author{
Tamie Nakajima, Shinobu Sato, Hiroshi Morita, Nobuo Yanagisawa
}

\begin{abstract}
Objectives-A nerve agent sarin (isopropyl methyl phosphonofluoridate) was released in Matsumoto city, Japan, on 27 June 1994. About 600 people were affected by the sarin, including seven who died. Fifty two rescuers engaged in helping the victims and 18 were affected. The aim was to investigate how the rescuers were affected by sarin.

Methods-Health examinations and a questionnaire survey were conducted with all rescuers.
\end{abstract}

Results-A rescuer who was one of the first engaged and who worked for about five hours in areas contaminated with sarin was admitted to hospital after poisoning; the others did not consult doctors although they showed slight muscarinic symptoms. The later the rescuers started their work, the less likely they were to experience symptoms of sarin exposure, and no one starting work 270 minutes after the original release of sarin was affected. The symptoms of exposure included ocular pain, darkness of visual field, nausea, vomiting, headache, rhinorrhea, narrowing of visual field, sore throat, fatigue, and dyspnoea, which were similar to those reported by the citizens who were sarin victims. There were no rescuers who had abnormal physical or neurological signs associated with sarin at the time of the physical examination conducted three weeks after the sarin release. A year after the sarin incident, the symptoms of all the rescuers had resolved.

Conclusions-Rescuers should protect themselves with appropriate clothing, gloves, and a mask to prevent a secondary disaster for at least 24 hours after a similar accident.

\section{(Occup Environ Med 1997;54:697-701)}

Keywords: sarin (isopropyl methyl phosphonofluoridate) poisoning; rescue team

Between 2240 and 2250 on 27 June 1994, 121 of the extremely toxic chemical sarin were released by the Oam cult terrorists in the central area of Matsumoto city, Japan, using a heater and fan from a truck (according to a report from the Police Office). It was drizzling at 2040 with a $0.2-1.2 \mathrm{~m} / \mathrm{s}$ wind from the south west and $93 \%$ humidity. However, less than 0.5 $\mathrm{mm}$ per hour of rain was falling during this time. Identification of the chemical was later confirmed by Nagano Research Institute for Health and Pollution. ${ }^{1}$ Seven inhabitants (five men and two women) were killed, and about 600 people were affected by the agent. ${ }^{23}$

To assist the victims, 52 rescuers worked in the area around the sarin release site. Some of them were affected by the toxic vapour, and one of them needed admission to hospital. A second attack with sarin later occurred in the Tokyo subway on 20 March $1995,{ }^{4}$ when rescuers also seemed to have been affected by the toxic vapour (according to a report from the Police Office). These findings suggest that a programme should be designed to protect rescuers from poisoning if a similar accident occurs.

To clarify when and how rescuers were exposed to the sarin, we conducted health examinations and a questionnaire survey three weeks after and one year after the Matsumoto sarin incident. This report describes the results of these surveys.

\section{Methods}

THE FIRST SURVEY: HEALTH EXAMINATION From the night of 27 June 1994 to the morning of 28 June 1994, 52 rescuers worked to assist the sarin victims. Usually, they worked as groups consisting of two or more colleagues. When the first team started, they thought that the episode might be a type of food poisoning judging by the symptoms of the victims, such as nausea. Nobody thought that a nerve agent had released intentionally. Thus throughout this rescue work, they wore ordinary cotton made uniforms, and no-one used protective clothes, mask, or gloves to shield them from the contamination of the toxic agent.

The health examination for all rescuers except for one who was admitted to hospital was conducted three weeks after the incident. Most were working in an area within $75 \mathrm{~m}$ from south to north and $110 \mathrm{~m}$ from east to west (area within the shaded area in the figure). After inquiring about the symptoms by using a questionnaire, physical examinations were performed. Serum pseudocholinesterase (S-ChE, 4.1-8.5 U) and acetyl cholinesterase in red blood cells (R-ChE, 1.2-2.0 U) were measured by Otsuka assay. Aspartate aminotransferase (AST, normal range 10-40 IU/1), alanine aminotransferase (ALT, 5-45 IU/L), $\gamma$ glutamyltranspeptidase $(\gamma \mathrm{GTP}, 0-80 \mathrm{mIU} / \mathrm{ml})$, zinc sulphate turbidity test (ZTT, 4-12 U), and blood cell counts were measured. Pulse rate, blood pressure, size of pupil, deep tendon reflexes, and vibratory and pain sensation of the legs were also investigated. The time when they started and stopped their work and the 
location of their work were also investigated by a public nurse.

THE SECOND QUESTIONNAIRE SURVEY

A year after the accident, the health status of the 52 rescuers was again surveyed. The questionnaire consisted of two sections: questions about personal information such as name, age, sex, and address and 13 questions on symptoms (headache, fatigue, feeling of heaviness in the head, insomnia, shoulder stiffness, asthenopia, difficulty reading and writing, blurred vision, husky voice, slight fever, palpitation, difficulty smoking, and having bad dreams). The questionnaire was distributed and collected by a leader of the rescuers after completion by each rescuer. Complete answers were collected from all the 52 rescuers.

\section{Results}

A RESCUER REQUIRING ADMISSION TO HOSPITAL Of the 52 rescuers, the most severely affected was a 45 year old man who required admission to hospital. He had a history of diabetes and was a smoker (20 cigarettes a day) and a regular drinker ( $27 \mathrm{~g}$ /day calculated for pure ethanol). At 2316 on 27 June, about 35 minutes after the release of the sarin, he arrived with two colleagues at the house nearest the site where the sarin was released ( $\mathrm{A}$ in the figure). When he arrived at the house, the male victim who phoned requiring an ambulance was waiting outside and entered the ambulance by himself. The most severely affected rescuer entered the house also to assist the other victims. Immediately after entering, he felt his vision darken. He found that a woman had collapsed with heart failure, and her daughter had also collapsed but she was conscious. He called one of his colleagues, and carried the two victims to the ambulance. After 11 minutes, the severely affected rescuer began to transfer three victims to a hospital, resuscitating the woman. At 0032 on 28 June he returned to an apartment near this house ( $\mathrm{C}$ in the figure) with two colleagues. Eighteen minutes later, he transferred five victims to the same hospital, and returned to the area at 0240 . He continued searching for victims for another two hours within buildings $B$ and $C$ (three victims had died in each) and outside of the buildings. Then he transferred one last victim to another hospital. About 0500 when he finished his activity, he had a headache, started vomiting, and was taken to a hospital. His heart rate was $72 \mathrm{bpm}$, blood pressure $120 / 78 \mathrm{~mm} \mathrm{Hg}$, and body temperature $36.2^{\circ} \mathrm{C}$. He showed severe miosis and conjunctivitis. After treatment with oxygen and atropine sulphate, his status improved.

Of the clinical laboratory tests, ALT (49 IU) and $\gamma$ GTP $(72 \mathrm{mIU} / \mathrm{ml})$ exceeded normal values. There were no abnormal signs on physical examination. In his urine, protein was weakly positive and sugar strongly positive. We did not measure R-ChE activity. In the afternoon of 28 June, he left the hospital for private reasons. The hospital charges of the man were covered by an accident allowance: he was the only officially acknowledged victim of sarin poisoning during his work.
Four weeks after the exposure to sarin, this rescuer still experienced narrowing of his visual field. This symptom had disappeared by the time of the questionnaire survey a year after the exposure.

\section{HEALTH EXAMINATION}

All rescuers showed normal pulse rate and pupil size. Vibratory or pain sensation was also normal. Some rescuers (10 people) had abnormal blood pressure (systolic blood pressure $\geqslant 140 \mathrm{~mm} \mathrm{Hg}$, diastolic blood pressure $\geqslant 90$ $\mathrm{mm} \mathrm{Hg}$ ), and seven people had exaggerated deep tendon reflexes. There were three people who had abnormal laboratory tests for liver function: one had high concentrations of AST, ALT, $\gamma$ GTP, and a high ZTT test, and the other had high AST, ALT, and ZTT. However, all had normal blood cell counts. No rescuer with lowered $\mathrm{R}-\mathrm{Che}$ and $\mathrm{S}-\mathrm{ChE}$ activities was found. The mean (SD) R-ChE and S-ChE activities in rescuers who started their work on 27 June 1994 were $162(0.15) U$ and 558(0.47) $\mathrm{U}$ respectively, and those who started their work on the next day were $176(0.21)$ and 633(1.03), respectively. R-ChE activity of rescuers who had symptoms associated with sarin was $174(0.21) \mathrm{U}$, which was similar to that $(175(0.21) \mathrm{U})$ of rescuers who did not.

Of 51 rescuers, 17 experienced some symptoms associated with sarin during their work: ocular pain (nine people), darkness of visual field (four), nausea or vomiting (three), headache (three), rhinorrhoea (three), narrowing of visual field (two), sore throat (two), fatigue (two), and dyspnoea (one). Almost all of the affected rescuers started their work within 150 minutes of the initial exposure. There was no relation between these symptoms and abnormality of blood pressure and of laboratory tests. All symptoms disappeared within three weeks of the sarin incident.

\section{RELATION BETWEEN TIME OF STARTING RESCUE} WORK AND ONSET OF SARIN RELATED SYMPTOMS Rescuers worked dividing into 18 teams, each consisting of a few members. The members of each team worked in the same situation. As reported above, the first team, with three rescuers, started their work in the house $20 \mathrm{~m}$ north east from the sarin release point at 2316 (A in the figure, table 1). All of them experienced symptoms associated with sarin (table 2).

The second rescue team started their work at 2355, more than one hour after the sarin release, and covered an area more remote (50 $m$ north east) from the release point than the first team (B in the figure). They worked there for 340 minutes, and all of them experienced sarin symptoms. However, the severity of symptoms was less than that reported by the first team, judging by the number of symptoms and consultation with doctors.

The third and fourth rescue teams engaged in tasks similar to those of the first team, but starting at 0014 on the next day and covering an area still further (70 $\mathrm{m}$ north east) from the release point ( $B$ and $C$ in the figure). One team transferred 12 victims to hospitals in four journeys; 


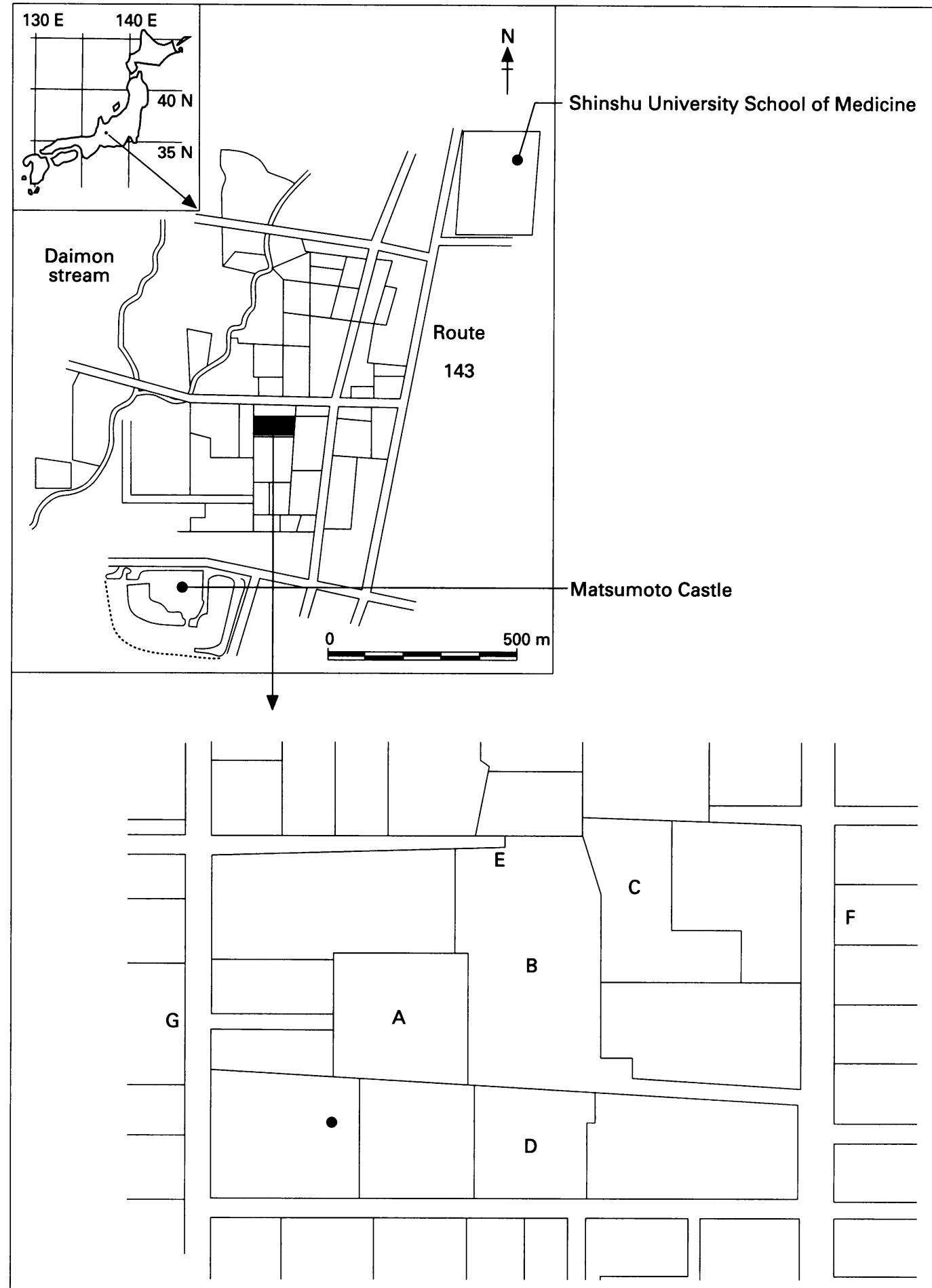

- Point where sarin was released

Geography of site where sarin was released in Matsumoto City. Fifty two rescuers worked within the shaded area. At the time when sarin was released, the weather in Matsumoto city was rainy at 2004 with a $0.2-1.2 \mathrm{~m} / \mathrm{s}$ wind from the south west, and 93\% humidity. (A) All members (five people) of the family were affected by sarin; one of them is still in a persistent vegetative state in hospital. (B) Three of the 15 inhabitants of this apartment died. (C) Three of the 10 inhabitants of this apartment died. (D) One of the eight inhabitants of this apartment died.

the other transferred nine victims in the same way. The two rescue teams worked in the area polluted by sarin for 125 minutes. Four of the six rescuers experienced sarin symptoms but they were less severe: the mean number of symptoms was less than half of those of the first team.

At 0032 on 28 June, the fifth team with three rescuers and a doctor arrived at an apartment ( $\mathrm{C}$ in the figure) $70 \mathrm{~m}$ north east of the sarin release site. They worked about 210 minutes in the area polluted by sarin to assist victims, and one of them, not the doctor, experienced symptoms similar to those of the third and fourth teams.

At about 0100 on 28 June, the sixth, seventh, and eighth teams started their work. One of the sixth team (three rescuers) worked at the same job as the first team: they transferred five 
Table 1 Relation between time starting work and onset of symptoms in rescuers

\begin{tabular}{|c|c|c|c|c|c|}
\hline $\begin{array}{l}\text { Group (number of } \\
\text { members) }\end{array}$ & Time starting work & $\begin{array}{l}\text { Primary working } \\
\text { site }^{\star}\end{array}$ & $\begin{array}{l}\text { Total working time } \\
\text { (min) }\end{array}$ & $\begin{array}{l}\text { Numbers of rescuers who } \\
\text { experienced symptomst }\end{array}$ & $\begin{array}{l}\text { Mean number of } \\
\text { symptoms } \neq\end{array}$ \\
\hline $1(3)$ & 27 June 2316 & A & 343 & 3 & 5 \\
\hline $2(3)$ & 2355 & A,B & 340 & 3 & 3 \\
\hline $3(3)$ & 28 June 0014 & B & 202 & 3 & 2 \\
\hline $4(3)$ & 0014 & $\mathrm{C}$ & 230 & 1 & 2 \\
\hline $5(3)$ & 0032 & C & 203 & 1 & 2 \\
\hline $6(2)$ & 0055 & E,D & 310 & 2 & 1 \\
\hline $7(3)$ & 0101 & C & 137 & 3 & 1 \\
\hline $8(4)$ & 0102 & B & 183 & 1 & 1 \\
\hline $9(4)$ & 0120 & $\mathrm{C}, \mathrm{B}$ & 233 & 0 & 0 \\
\hline $10(2)$ & 0130 & $\mathrm{C}, \mathrm{B}$ & 233 & 0 & 0 \\
\hline $11(3)$ & 0157 & $\mathrm{C}$ & 40 & 0 & 0 \\
\hline $12(3)$ & 0216 & G & 15 & 0 & 0 \\
\hline $13(1)$ & 0230 & $\mathbf{E}$ & 180 & 0 & 0 \\
\hline $14(6)$ & 0230 & $\mathrm{~F}$ & 60 & 0 & 0 \\
\hline $15(2)$ & 0300 & $\mathrm{C}$ & 180 & 1 & 1 \\
\hline $16(4)$ & 0300 & $\mathbf{E}$ & 90 & 0 & 0 \\
\hline $17(1)$ & 0330 & $\overline{\mathrm{A}}$ & 90 & 0 & 0 \\
\hline $18(2)$ & 0400 & $\mathbf{E}$ & 120 & 0 & 0 \\
\hline
\end{tabular}

*Letter represents the working place as shown in figure 1 .

†Rescuers with symptoms as determined during health examination including one rescuer abmitted to hospital.

$\ddagger$ The sum of numbers of symptoms reported by each rescuer was divided by the number of people with symptoms.

victims to a hospital; they worked in the polluted area for about 120 minutes. All of them experienced some symptoms. The remaining two teams (six rescuers) worked to assist the victims in different areas $(B, C, D$, and $\mathrm{E}$ in the figure) for two to five hours, and three of them experienced symptoms.

As well as these eight teams, another 10 rescue teams coming from neighbouring districts started working after 0100 . One rescuer of these teams experienced ocular pain and the others were symptom free.

No rescuer experienced any symptoms associated with sarin a year after the incident.

\section{Discussion}

Based on the health examinations, the number of rescuers affected by sarin was estimated to be $18(34.6 \%)$. The symptoms experienced by rescuers were similar to those experienced by victims, which have been reported elsewhere. ${ }^{2}{ }^{3}$ Of the victims living in a block where the rescuers worked, seven inhabitants were killed; $76 \%$ of all inhabitants experienced some symptoms associated with sarin. Of these victims, $28 \%$ required admission to hospital; $23 \%$ consulted doctors. ${ }^{2}$ These results suggest that the severity of sarin poisoning of rescuers seemed to be milder than those of resident victims. Unlike the resident victims, all rescuer victims were asymptomatic a year after the incident. As well as these results, the fact that no-one who started working more than 270 minutes after sarin release was affected, is much more important. The reason that the severity of sarin poisoning of the rescuers is milder than that of the resident victims may be due to starting their work on average 0.5-1 hours later than the sarin release.

Miosis and depressed R-ChE activity were the most common findings seen in sarin intoxication. ${ }^{5-11}$ We detected neither a narrowing of pupil size nor a lowered R-ChE activity in examinations conducted at three weeks after the incident except for one rescuer admitted to hospital. Both signs presumably would have been seen in some rescuers in the acute stage, judging by their symptoms. This is supported by the findings from resident victims that lowered R-ChE activity is correlated with complaints of darkness of visual field, narrowing of vision, ocular pain, vomiting, and headache, ${ }^{2}$ which were retrospectively reported by many rescuers.

It is noteworthy that the percentage of affected rescuers was dependent on the time of starting work. All affected rescuers started work before 0300 , which was about 270 minutes after the release of the gas. This does not mean that the area was entirely safe after several hours of sarin emission, as a survey of victims living in this same region identified many people who experienced sarin symptoms after $0300 .^{2}$ Some victims were reporting their first symptoms as late as 20 hours after the incident, presumably because of the cumulative effect of low level exposure. Indeed, samples taken at 1100 the next morning found sarin in the air inside of the nearest house ( $A$ in

Table 2 Number of people from each group with a specific symptom

\begin{tabular}{ll}
\hline Group (number of members) & Number of symptoms \\
\hline $1(3)$ & $\begin{array}{l}\text { Rhinorrhoea (2), coughing (1), darkness of visual field (2), narrowing of visual field } \\
\text { (3), ocular pain (2), blurriness of vision (1), headache (2), vomiting (1) } \\
\text { Dyspnoea (1), darkness of visual field (2), narrowing of visual field (1), ocular pain } \\
\text { (3), flickering (1), vomiting (1); }\end{array}$ \\
$\begin{array}{l}\text { Rhinorrhoea (1), sore throat (1), ocular pain (1), flickering (1), headache (1), } \\
\text { vomiting (1), fatigue (1) }\end{array}$ \\
$\begin{array}{l}\text { Increase of lacrimation (1), fatigue (1); } \\
\text { Rhinorrhoea (1), darkness of visual field (1), sore throat (1), ocular pain (2), headache } \\
\text { (1), vomiting (1) }\end{array}$ \\
$\begin{array}{l}\text { Ocular pain (1) } \\
6(2), 7 \text { (3), and } 8 \text { (4) }\end{array}$ \\
\hline $5(2)$ & \\
\hline
\end{tabular}


the figure), and also in the water samples from a pond outside. ${ }^{1}$

In the most severely affected rescuer, the activities of ALT and GTP exceeded normal values. This may be due to a history of diabetes, not exposure to sarin, as there were no resident victims with abnormal values. ${ }^{3}$

These results suggest that rescuers should work with suitable clothes, gloves (heavy rubber gloves), and a mask (containing a charcoal filter), as pointed out by Sidell and Borak, ${ }^{10}$ to prevent contamination with toxic substances, and minimise sarin exposure for at least 24 hours after the gas has been released in any incident similar to that of the Matsumoto case. This will be important to prevent a secondary disaster, although intoxication in rescue teams was relatively mild in the Matsumoto incident.
1 Fujishima $\mathrm{H}$, ed. $A$ report analyzing the toxic substance attack of Matsumoto city. Nagano, Japan: Nagano Research Institute for Health and Pollution, 1995. (In Japanese.)

2 Yanagisawa N, ed. Report of the toxic gas attack in Matsumoto Matsumoto, Japan: Matsumoto Regional Comprehensive Medical Council, 1995. (In Japanese.)

3 Morita H, Yanagisawa N, Nakajima T, Shimizu M, Hirabayashi $\mathrm{H}$, Okudera $\mathrm{H}$, et al. Sarin poisoning of citizens in yashi $\mathrm{H}$, Okudera $\mathrm{H}$, et al. Sarin poiso

4 Suzuki T, Morita H, Ono K, Maekawa K, Nagai R, Yazaki Y. Sarin poisoning in Tokyo subway. Lancet 1995;345:980.

5 World Health Organisation. Health aspects of chemical and biological weapons. Report of a World Health Organisation group of consultations. Geneva: WHO, 1970:24-39.

6 Dunn CA, Sidell FR. Progress in medical defense against nerve agents. $¥ A M A$ 1989;262:649-52.

7 Grob D, Harvey AM. The effects and treatment of nerve gas poisoning. Am $\mathcal{F}$ Med 1953;14:52-63.

8 Grob D, Harvey JC. Effects in man of the anticholinesterase compound sarin (isopropyl methylphosphonofluoridate). $\mathcal{F}$ Clin Invest 1958;37:350-68.

9 Gunderson CH, Lehmann CR, Sidell FR, Jabbari B. Nerve agents: a review. Neurology 1992;42:946-50.

10 Sidell FP, Borak J. Chemical warfare agents: II nerve agents. Ann Emerg Med 1992;21:865-71.

11 Rengstorff $\mathrm{H}$. Accidental exposure to sarin: vision effects. Arch Toxicol 1985;56:201-3.

\section{Vancouver style}

All manuscripts submitted to Occup Environ Med should conform to the uniform requirements for manuscripts submitted to biomedical journals (known as the Vancouver style.)

Occup Environ Med, together with many other international biomedical journals, has agreed to accept articles prepared in accordance with the Vancouver style. The style (described in full in the $\mathcal{F} A M A[1]$ ) is intended to standardise requirements for authors, and is the same as in this issue.

References should be numbered consecutively in the order in which they are first mentioned in the text by Arabic numerals on the line in square brackets on each occasion the reference is cited (Manson[1] confirmed other reports[2][3][4][5]). In future references to papers submitted to Occup Environ Med should include: the names of all authors if there are seven or less or, if there are more, the first six followed by et al; the title of journal articles or book chapters; the titles of journals abbreviated according to the style of Index Medicus; and the first and final page numbers of the article or chapter. Titles not in Index Medicus should be given in full. Examples of common forms of references are:

1 International Committee of Medical Journal Editors. Uniform requirements for manuscripts submitted to biomed journals. $\mathfrak{F} A M A$ 1993;269:2282-6.

2 Soter NA, Wasserman SI, Austen KF. Cold urticaria release into the circulation of histmaine and eosinophil chemotactic factor of anaphylaxis during cold challenge. N Engl F Med 1976;294:687-90.

3 Weinstein L, Swartz MN. Pathogenic properties of invading micro-organisms. In: Sodeman WA Jr, Sodeman WA eds. Pathologic physiology, mechanisms of disease. Philadelphia: W B Saunders, 1974:457-72. 